\title{
Vegetation of mono-layer landfill cover made of coal bottom ash and soil by compost application
}

\author{
Seul Bi Lee ${ }^{1}$, Sang Yoon $\mathrm{Kim}^{2}$, Chan $\mathrm{Yu}^{3}$, Soon-Oh Kim ${ }^{4}$, Pil Joo Kim ${ }^{2,5 \#}$ \\ ${ }^{1}$ Department of Agricultural Environment, National Academy of Agricultural Science (NAAS), Rural Development Administration \\ (RDA), Suwon, South Korea \\ ${ }^{2}$ Division of Applied Life Science (BK 21 Program), Gyeongsang National University, Jinju, South Korea \\ ${ }^{3}$ Department of Agricultural Engineering, Gyeongsang National University, Jinju, South Korea \\ ${ }^{4}$ Department of Earth and Environmental Sciences, Gyeongsang National University, Jinju, South Korea \\ ${ }^{5}$ Institute of Agriculture and Life Science, Gyeongsang National University, Jinju, South Korea; \\ \#Corresponding Author: pjkim@gnu.ac.kr
}

Received 10 April 2013; revised 16 May 2013; accepted 1 June 2013

Copyright (C) 2013 Seul Bi Lee et al. This is an open access article distributed under the Creative Commons Attribution License, which permits unrestricted use, distribution, and reproduction in any medium, provided the original work is properly cited.

\section{ABSTRACT}

Monolayer barriers called evapotranspiration (ET) covers were developed as alternative final cover systems in waste landfills but high-quality soil remains a limiting factor in these cover systems. Coal bottom ash was evaluated to be a very good alternative to soil in previous tests and a combination of soil $\left(65 \% \mathrm{wt} \cdot \mathrm{wt}^{-1}\right)$ and coal bottom ash $\left(35 \% w t \cdot w^{-1}\right)$ was evaluated to be the most feasible materials for ET cover systems. In our pot test, selected manure compost as soil amendment for the composite ET cover system, which was made of soil and bottom ash at ca. 40 $\mathrm{Mg} \cdot \mathrm{ha}^{-1}$ application level was very effective to promote vegetation growth of three plants; namely, garden cosmos (Cosmos bipinnatus), Chinese bushclover (Lespedeza cuneata), and leafy lespedeza (Lespedeza cyrtobotrya). To evaluate the effect of compost application on plant growth in an ET vegetative cover system, two couples of lysimeters, packed with soil and a mixture of soil and bottom ash, were installed in a pilot landfill cover system in 2007. Manure composts were applied at the rates of 0 and $\mathbf{4 0}$ $\mathrm{Mg} \cdot \mathrm{ha}^{-1}$ before sowing the five plant species, i.e. indigo-bush (Amorpha fruticosa), Japanese mugwort (Artemisia princeps, Arundinella hirta, Lespedeza cuneata, and Lespedeza cyrtobotrya). Unseeded native plant (green foxtail, Setaria

\footnotetext{
${ }^{*}$ This work was supported by the Development of the value-added functional fertilizers using coal combustion by-products of the Korea Institute of Energy Technology Evaluation and Planning (KETEP) grant funded by the Korea government Ministry of Knowledge Economy (No. KETEP: 2010T100100611).
}

viridis) was dominant in all treatments in the $1^{\text {st }}$ year after installation while the growth of the sown plants significantly improved over the years. Total biomass productivity significantly increased with manure compost application, and more significantly increased in the composite ET cover made of soil and bottom ash treatment compared to the single soil ET cover, mainly due to more improved soil nutrient levels promoting vegetation growth and maintaining the vegetation system. The use of bottom ash as a mixing material in ET cover systems has a strong potential as an alternative to fine-grained soils, and manure compost addition can effectively enhance vegetative propagation in ET cover systems.

Keywords: Bottom Ash; Coal Ash; Compost Application; Evapotranspiration (ET) Cover; Monolayer Barrier

\section{INTRODUCTION}

Landfills undergoing closure must be covered with a final cover that minimizes the long-term migration of liquids through the landfill [1]. The capping system can vary from simple soil cover to multiple layers of earthen and geosynthetic materials [2]. Several studies [3,4] have explored various alternative cover technologies for final closure of waste landfills. Among them, monolayer barriers called as evapotranspiration (ET) cover are covers that include a thick layer of fine-grained soil generally covered with a layer of vegetated topsoil and alternative final cover systems to the conventional cover system. 
Different to conventional cover system designs that use materials with low hydraulic permeability, ET cover systems use water balance components to minimize percolation. These cover systems rely on the properties of soil to store water until it is either transpired through vegetation or evaporated from the soil surface. This type of thick cover encourages water storage and enhances ET yearround, rather than just during the growing seasons. The soil allows water storage, which, when combined with the vegetation, will increase ET. These soil barriers can be cost effective when large quantities of fine grained soil requiring little processing is available on site. However, most of landfill sites in the world are struggling to find large amounts of good quality soil.

The materials used in soil-based cover systems are either natural materials, modified soils, synthetic material, or waste materials. Well-graded fine-grained compacted soils are usually selected in case of natural soils. If available, different types of clay are the most likely choice because of their low hydraulic conductivity and adequate performance in eliminating the fluids transport through landfills. There has been growing interest in using waste materials as alternative hydraulic barriers for conventional materials in lining and covering landfills. This is apparent where clay and other fine soils are not readily available and usually require high prices for transport from remote locations. Another reason is attributed to the huge amounts of generated wastes and the elevating costs associated with their disposal [5].

Among the waste materials that have already been used as substitute for soil-based covers are fly ash, slags from iron and steel-making, non-ferrous slags, domestic refuse incinerator ash, overburden materials, dredged silts, construction rubble, wastewater treatment sludges, and paper mill sludges. Mollamahmutoglu and Yilmaz [6] found that $20 \%$ bentonite-class F fly ash was suitable as a liner or cover material at waste disposal areas, and Kim et al. [7] found in the lab test that coal bottom ash among four industrial byproducts (blast furnace and steel refining slags, coal bottom ash, and phospho-gypsum) was the most feasible alternative of soil in the ET cover system and a mixture of ca. $35 \%$ of bottom with soil was the most suitable [8]. Bottom ash has a particle size generally within the range of $0.1-10 \mathrm{~mm}$ [9]. The chemical constituents of bottom ash can vary greatly depending on the coal type, source, and plant operating parameters. Major constituents include calcium $(\mathrm{Ca})$, aluminum (Al), iron $(\mathrm{Fe})$, magnesium $(\mathrm{Mg})$, potassium $(\mathrm{K})$, silicone $(\mathrm{Si})$, sodium $(\mathrm{Na})$ and titanium $(\mathrm{Ti})$. These constituents typically constitute up to $95 \%$ of the mass of the ash. Of these materials, $\mathrm{Ca}, \mathrm{Fe}, \mathrm{Mg}, \mathrm{K}$ and $\mathrm{Si}$ are essential plant nutrients [9].

However, fast re-vegetation could be of particular importance to efficiently establish ET cover systems, espe- cially in the case of the industrial byproduct utilization, since leachate volume can decrease as a result of the soil-plant systems ET [10]. Plants within a soil-plant system can evapotranspirate a large amount of incoming water, including landfill leachate. Plant ET potential closely depends on plant growth, and therefore, soil fertility management can be very important. Manure compost application could be a simple and good amendment to improve soil fertility and plant growth. The benefits of using manure compost as an organic soil amendment may be seen in agricultural land. Recently animal wastes represent a disposal problem while offering potential soil amendment benefits in most countries. Since cattle feeding industry is continuously expanding in Korea, manure compost utilization in landfill cover as an amendment could be a good disposal area of manure.

In this view, the objective of this study was to determine the optimum application levels of manure based compost as a soil amendment in the ET cover system, which was developed by mixing bottom ash $(35 \%$, $\left.\mathrm{wt} \cdot \mathrm{wt}^{-1}\right)$ and soil $\left(65 \%, \mathrm{wt} \cdot \mathrm{wt}^{-1}\right)[7,8]$, and then evaluate the effect of compost application on vegetation development and soil properties.

\section{MATERIALS AND METHODS}

\subsection{Selection of Bottom Ash and Soil}

In previous studies $[7,8]$, the bottom ash among four industrial byproducts (blast furnace slag and steel refining slag from iron making factories, coal bottom ash for electric power station, and phospho-gypsum from chemical fertilizer factory) was selected as the best mixing material with soil for installing an ET cover system. In this test, the same bottom ash and soil were selected in the pot test and pilot landfill cover system, with the purpose of determining the optimum compost application rate and its field applicability, respectively.

The coal bottom ash was collected from a thermal power plant in Hadong Power Plant of Kwangyang, South Korea and air-dried and sieved to $<4 \mathrm{~mm}$ for the pot and pilot tests. Characteristics of coal bottom ash were alkaline $(\mathrm{pH} 8.9)$ and had high concentration of available phosphorus. The soil that was collected from an alpine area in Gyeongsang National University campus, Jinju City, South Korea campus had a pH of 6.1 with low nutrient contents (Table 1).

\subsection{Preparation of Pot Test}

To determine the effect of compost application on the vegetative growth of three selected plants, namely, garden cosmos (Cosmos bipinnatus), Chinese bushclover (Lespedeza cuneata), and leafy lespedeza (Lespedeza cyrtobotrya), which are generally grown in landfill cover plantations in Korea, a horticultural seedling bed tray (L 
Table 1. Chemical properties of soil and coal bottom ash used in the pot and vegetative cover pilot tests.

\begin{tabular}{lcc}
\hline Parameters & Soil & Coal bottom ash \\
\hline $\mathrm{pH}\left(1: 5\right.$ with $\left.\mathrm{H}_{2} \mathrm{O}\right)$ & 6.1 & 8.9 \\
Electrical conductivity $\left(\mathrm{dS} \cdot \mathrm{m}^{-1}\right)$ & 0.22 & 1.4 \\
Organic matter $\left(\mathrm{g} \cdot \mathrm{kg}^{-1}\right)$ & 14.5 & 33.1 \\
Available $\mathrm{P}_{2} \mathrm{O}_{5}\left(\mathrm{mg} \cdot \mathrm{kg}^{-1}\right)$ & 6.1 & 551 \\
Exchangeable cations $\left(\mathrm{cmol}^{+} \cdot \mathrm{kg}^{-1}\right)$ & & \\
$\quad \mathrm{K}$ & 0.12 & 0.03 \\
$\mathrm{Ca}$ & 4.3 & 4.9 \\
$\mathrm{Mg}$ & 2.6 & 1.60 \\
$\quad \mathrm{Na}$ & 0.3 & 0.31 \\
Soil texture & Silt Loam (SiL) & - \\
\hline
\end{tabular}

$80 \mathrm{~cm} \times \mathrm{W} 60 \mathrm{~cm} \times$ D $20 \mathrm{~cm}$ size) was filled with the bottom ash $(35 \%)$ and soil $(65 \%)$ mixture. Four levels of compost $\left(0,20,40\right.$, and $\left.80 \mathrm{Mg} \cdot \mathrm{ha}^{-1}\right)$ were applied on the surface and totally hand-mixed. The compost material was purchased from a local market with typical characteristics of a swine manure compost $(\mathrm{pH} \mathrm{6.8,} \mathrm{organic}$ matter $406 \mathrm{~g} \cdot \mathrm{kg}^{-1}$, total $\mathrm{N} 11 \mathrm{~g} \cdot \mathrm{kg}^{-1}, \mathrm{C} / \mathrm{N}$ ratio 24 , total $\mathrm{P}_{2} \mathrm{O}_{5} 19 \mathrm{~g} \cdot \mathrm{kg}^{-1}$, and total $\mathrm{K}_{2} \mathrm{O} 13 \mathrm{~g} \cdot \mathrm{kg}^{-1}$ ). Thirty seeds of each plant were seeded in a line of two rows in a seedling bed with constant intervals $(10 \mathrm{~cm} \times 5 \mathrm{~cm})$ on April 9,2006 , grown under ambient conditions in a greenhouse, and harvested on November 20, 2006 for evaluating the total plant biomass. Moisture contents were controlled during the plant cultivation period following the conventional method for upland plants recommended by NAIST of Korea [11]. The treatments were replicated with three times.

\subsection{Installation of the Vegetative Cover Pilot System}

A vegetation test was conducted on a pilot scale using the lysimeter method. Four sets of lysimeter, each set with a dimension of $\mathrm{H} 1.2 \mathrm{~m} \times \mathrm{W} 2 \mathrm{~m} \times \mathrm{L} 6 \mathrm{~m}$ size, were constructed on the campus of Gyeongsang National University, Jinju, South Korea (Figure 1). This study was carried out in a typical monsoonal climate within a temperate zone and the annual mean temperature and precipitation were recorded to be $13.1^{\circ} \mathrm{C}$ and $1513 \mathrm{~mm}$, respectively, over a 30-year period (1980-2010) [12].

A piezometer constructed of $\mathrm{PCV}$ tubes, each $5 \mathrm{~cm}$ in diameter, was put into the lysimeter for ground water sampling, accumulation and level control. The piezometer was closed from the top and filtered from the bottom in a gravel layer. The gravel layer with a particle diameter of 10 to $20 \mathrm{~mm}$ allowed drainage of percolating water.

The four sets of lysimeter were packed with a mixture of soil $(65 \%)$ and bottom ash $(35 \%$, two sets) and the pure soil (two sets). In the pot test, ca. $40 \mathrm{Mg} \cdot \mathrm{ha}^{-1}$ of manure compost was evaluated as the optimum level in this ET cover condition. To determine the effect of compost application on re-vegetation, compost was applied

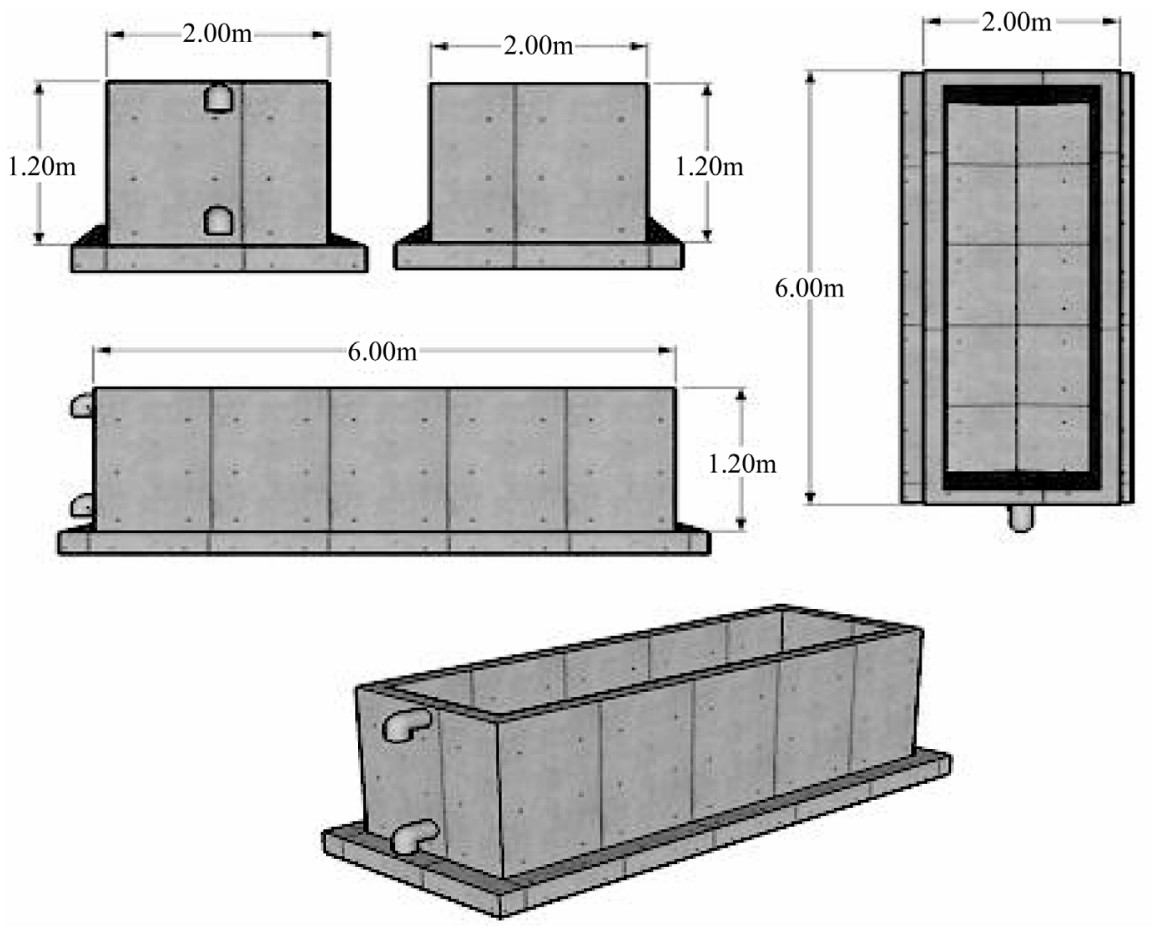

Figure 1. Layout of the ET landfill lysimeter chamber used in the vegetative cover pilot test. 
with rates of 0 and $40 \mathrm{Mg} \cdot \mathrm{ha}^{-1}$, and then mixed manually at $20 \mathrm{~cm}$ depth. Selected plant seeds (Amorpha fruticosa, Artemisia princeps, Arundinella hirta, Lespedeza cuneata, Lespedeza cyrtobotrya) were broadcasted evenly and covered with a thin layer of soil in all lysimeters in the mid May, 2007. Thereafter, the vegetation was maintained without any further fertilizer or tillage activities and the above-ground parts of the plants were harvested around the end of October in 2007 and 2009, air-dried, and weighed for total biomass productivity.

\subsection{Investigation of Plant Biomass Productivity and Soil Chemical Properties}

The vegetative biomass was harvested in $0.5 \mathrm{~m} \times 1.0$ $\mathrm{m}$ size around the late October in the $1^{\text {st }}$ and $3^{\text {rd }}$ years after the installation (2007). The harvested plant biomass was oven-dried at $70^{\circ} \mathrm{C}$ for $72 \mathrm{hr}$, and then weighed on dry weight basis, which was replicated three times.

The compost used in the pot and pilot tests were ovendried at $70^{\circ} \mathrm{C}$ for $72 \mathrm{hr}$, ground and then digested using a ternary solution $\left(\mathrm{HNO}_{3}: \mathrm{H}_{2} \mathrm{SO}_{4}: \mathrm{HClO}_{4}, 10: 1: 4\right.$

volume volume ${ }^{-1}$ ) to determine the total $\mathrm{P}$ and $\mathrm{K}$ contents. Total $\mathrm{C}$ and $\mathrm{N}$ concentrations were quantified by CHNS Analyzer (CHNS-932 Analyzer, Leco, USA).

Surface soil samples $(0-15 \mathrm{~cm})$ were collected from the pilot system at the plant biomass harvesting stage in the $1^{\text {st }}$ and $3^{\text {rd }}$ years after the installation, air-dried and sieved $(<2 \mathrm{~mm})$ for chemical analysis. The chemical properties were analyzed as follows: $\mathrm{pH}$ (1:5 water extraction), organic matter content (Walkley and Black method [13], and levels of exchangeable $\mathrm{Ca}^{2+}, \mathrm{Mg}^{2+}, \mathrm{K}^{+}$, and $\mathrm{Na}^{+}$(1 M NH 4 -acetate $\mathrm{pH}$ 7.0, AA, Shimazu 660). The available $\mathrm{P}$ content was determined using the Lancaster method [14]. Heavy metals were extracted using the $0.1 \mathrm{M} \mathrm{HCl}$ solution and quantified using the ICPOES (inductively coupled plasma optical emission spectrophotometer, GBC model X-100, Australia).

Statistical analysis was performed with the SAS package, version 8.2. One-way ANOVA was carried out to compare the means of the different treatments where significant $F$ values were detected.

\section{RESULTS AND DISCUSSION}

\subsection{Evaluation of Reasonable Compost Application Level}

The biomasses of the selected plants was significantly increased with increasing compost application rates up to $40 \mathrm{Mg} \cdot \mathrm{ha}^{-1}$, but thereafter sharply decreased. Similar growth trends were observed in all treatments as compared to the control, irrespective of the plant species and ET cover soil composition (Figure 2). Using a quadratic response model, the dry biomass yield of Cosmos bipinnatus in the composite ET cover that was made of bottom ash and soil was affected by the compost application rates as "Yield $\left(\mathrm{kg} \cdot \mathrm{ha}^{-1}\right)=2234+94.7$ Compost -0.98 Compost $^{2}$ (model $\mathrm{R}^{2}=0.756^{* *}$ )", where compost application rate is expressed as $\mathrm{Mg} \cdot \mathrm{ha}^{-1}$. Using this equation, the maximum biomass yield was ca. $4522 \mathrm{~kg} \cdot \mathrm{ha}^{-1}$ at ca. $40 \mathrm{Mg} \cdot \mathrm{ha}^{-1}$ compost application level, which is approximately two times higher than the biomass yield (ca. $2234 \mathrm{~kg} \cdot \mathrm{ha}^{-1}$ ) in the control (no compost application). The other two plant species showed the maximum biomass yields at similar levels of compost application (ca. $40 \mathrm{Mg} \cdot \mathrm{ha}^{-1}$ ), and the dry biomass yield was increased by ca. $25 \%$ and ca. $45 \%$ in Lesoedeza cuneata and Lespedeza cyrtobotrya plants, respectively compared with the control. Almost similar plant growth responses were observed between the single soil ET cover and manure compost application.

In Korea, compost application at approximately 10 $20 \mathrm{Mg} \cdot \mathrm{ha}^{-1}$ is generally recommended for agricultural soils [15]. However, the fertility of alpine soil in this study was very low at an organic matter of $14.5 \mathrm{~g} \cdot \mathrm{kg}^{-1}$ and available phosphorus of $6 \mathrm{mg} \mathrm{P} \cdot \mathrm{kg}^{-1}$ contents (Table 1) relative to the 24 and $235 \mathrm{mg} \cdot \mathrm{kg}^{-1}$ of the average organic matter and available phosphorus contents of a typical upland soil in Korea in the 1990s, respectively [15]. As a result, the highest dry biomass yield was observed in this ET cover system at higher compost application rate compared with the typical upland soil, irrespective of the ET cover soil composition. In general, the manure compost can act as effective surface mulch, increase the concentration of soil organic matter, improve tilth and water-holding capacity, suppress weeds, and provide a long-term supply of nutrients as the organic material decomposes [16,17]. For these reasons, compost application has been advocated as one component of sustainable agriculture [18,19].

However, the significantly improved biomass productivities of Lesoedeza cuneata and Lespedeza cyrtobotrya were observed in the composite ET cover of soil (65\%) and bottom ash (35\%) compared with those in the single soil ET covers. Since coal combustion ash has high content of plant available inorganic nutrients and alkaline $\mathrm{pH}$, the beneficial effects of coal ash as a soil amendment is well known [21-27]. The addition of alkaline coal ash, which has a pH over 9.0 [20], can reduce soil acidity to a level suitable for agriculture [21] and can increase the availability of $\mathrm{Si}, \mathrm{Na}, \mathrm{K}, \mathrm{Ca}, \mathrm{Mg}, \mathrm{B}, \mathrm{S}$ and other trace nutrients [22-27]. The commercial use of coal ash as a fertilizer in crop production is uncommon in most countries, because coal ashes may also contain non-essential elements that adversely affect crop, soil and groundwater quality (e.g., As, B, Cd, Se) [28-30]. Despite potential negative effects on environmental quality, since coal 


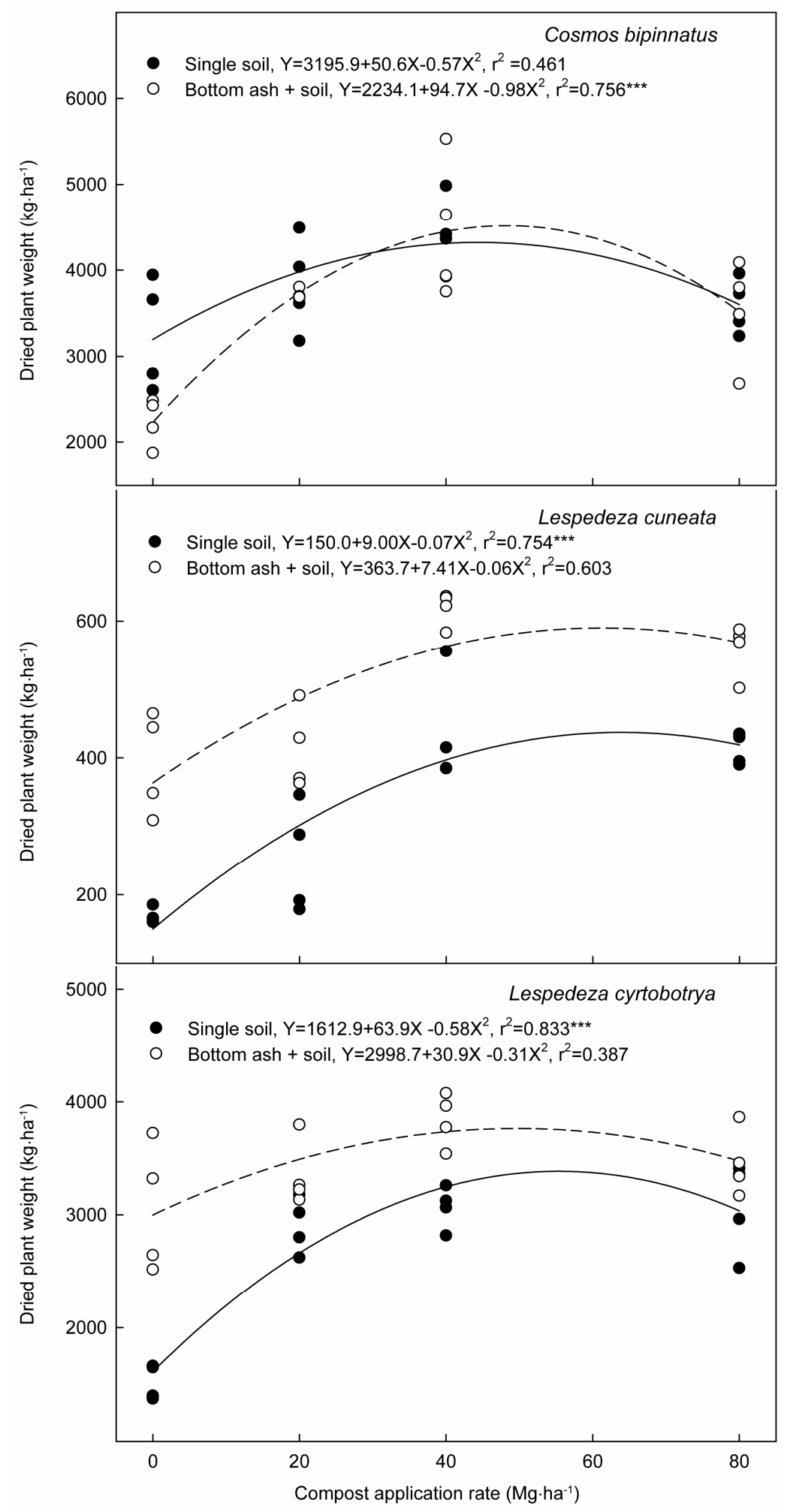

Figure 2. Changes of plant biomasses in the composite (soil and bottom ash mixture) and the single soil ET covers amended with different rates of manure compost in the pot test.

continues to be the prime source of energy in Korea and contains high concentration of plant essential inorganic elements, the utilization of coal ash is likely to remain a serious issue. 


\subsection{Effect of Bottom Ash and Compost on Re-Vegetation in the Vegetative Cover Pilot System}

The vegetation compositions were changed in the landfill ET covers over the study years. Five different kinds of herbal grass and bush trees (Amorpha fruticosa, Artemisia princeps, Arundinella hirta, Lespedeza cuneata, Lespedeza cyrtobotrya) were sown in late June, 2007, and thereafter managed under the same condition for 3 years. However, green foxtail (Setaria viridis) which is a native plant in Korea was found as the dominant plant species in all treatments in the $1^{\text {st }}$ year after the installation. Biomass productivity of the other sown plant species was very low probably due to late seeding. The system construction and stabilization was somewhat delayed and the plants were only sown in early summer season, not in spring. However, the proportion of the green foxtail to the total vegetation gradually declined over the 3 study years, but the growth of the sown plants significantly improved.

Total plant biomass productivity significantly increased with $40 \mathrm{Mg} \cdot \mathrm{ha}^{-1}$ manure compost application, irrespective of the ET cover soil composition (Figure 3). In the $1^{\text {st }}$ year, total plant biomass yield was ca. 1.27 and $1.43 \mathrm{Mg} \cdot \mathrm{ha}^{-1}$ (on dry weight basis) in the single soil ET cover and the composite ET cover, respectively, but increased to ca. 1.73 and 1.94 times with the $40 \mathrm{Mg} \cdot \mathrm{ha}^{-1}$ compost application. The effect of compost application on improving plant growth became clearer in the sterile soil ET cover compared with the high organic matter containing composite ET cover as time elapsed. In the $3^{\text {rd }}$ year after the installation, the total plant biomass was ca. 3.67 $\mathrm{Mg} \cdot \mathrm{ha}^{-1}$ on dry weight basis in the single soil ET cover, which increased to ca. $8.49 \mathrm{Mg} \cdot \mathrm{ha}^{-1}$ with 40 $\mathrm{Mg} \cdot \mathrm{ha}^{-1}$ compost application. In comparison, the plant biomass productivity was not significantly different between 0 and $40 \mathrm{Mg} \cdot \mathrm{ha}^{-1}$ compost application. This different response of plant growth characteristics with compost application in the $3^{\text {rd }}$ year might have been caused by the difference of soil fertility between the two different ET cover soils. Among the soil chemical properties investigated at the plant harvesting stage in the $3^{\text {rd }}$ year (2009) after the installation, soil fertility status such as $\mathrm{pH}$, organic matter, and available inorganic nutrient contents were more favorable to plant growth in the composite ET layer than in the single soil layer (Table 1). In particular, the organic matter content of the composite ET covers was ca. $32-36 \mathrm{~g} \cdot \mathrm{kg}^{-1}$, which is much more than the organic matter content of $1.6-2.1 \mathrm{~g} \cdot \mathrm{kg}^{-1}$ in the single soil ET cover. The studied coal ash had ca. 33 $\mathrm{g} \cdot \mathrm{kg}^{-1}$ of organic matter. Therefore, coal bottom ash addition $(35 \%)$ in the composite ET cover preparation significantly increased the organic matter content, and might have improved plant growth.

Soil organic matter is one of the most important constituents of soils due to its capacity in affecting plant growth indirectly and directly [31]. Indirectly, it improves the chemical and physical conditions of soils by increasing cation exchange capacity, buffering capacity, and enhancing aggregation, aeration and water retention. Improvement of soil biological properties affects soil microbial diversity and population, thereby creating a suitable environment for root growth of plants and soil

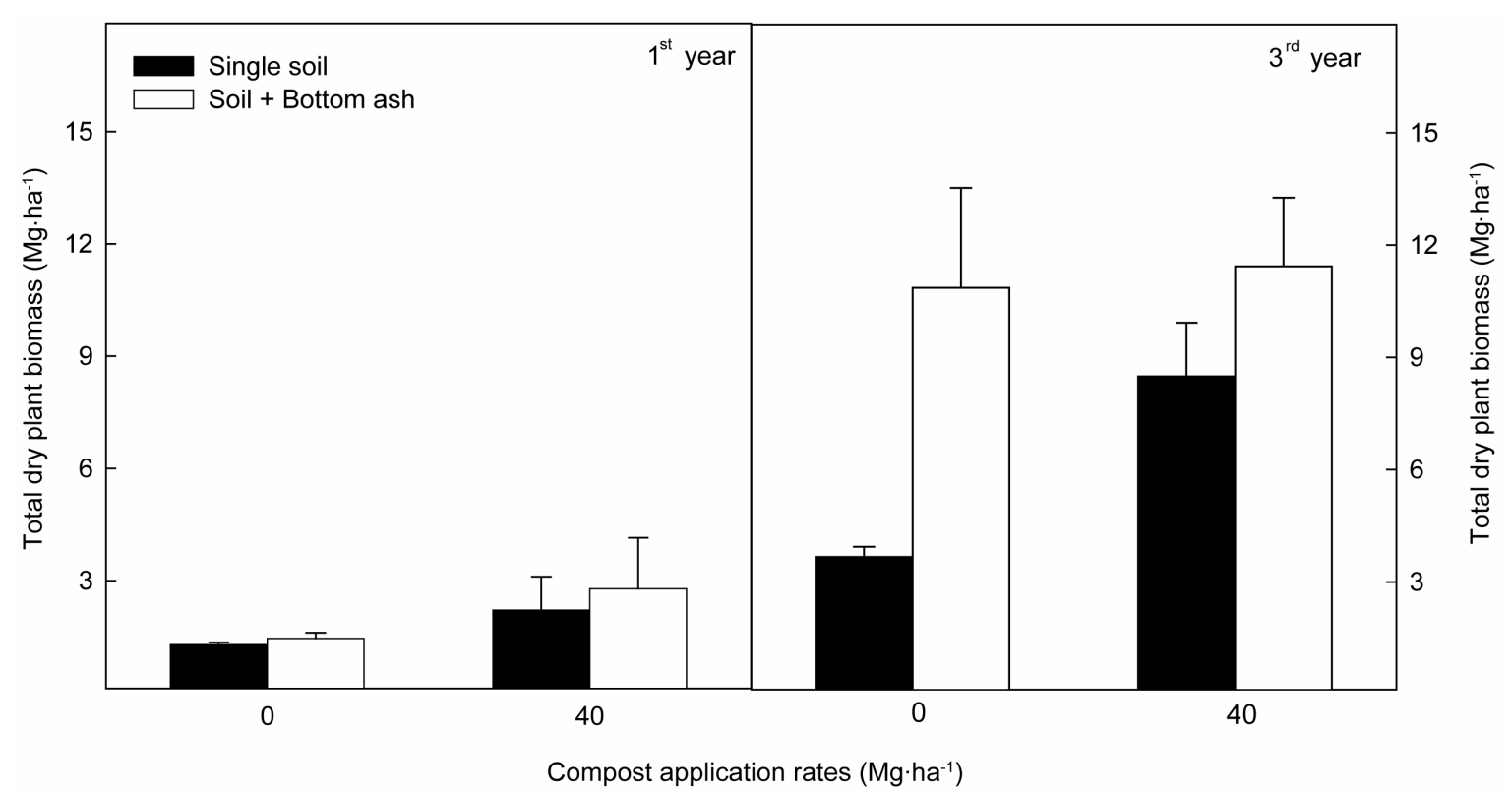

Figure 3. Plant biomass productivities in the composite (soil and bottom ash mixture) and the single soil ET covers amended with different rates of manure compost in the vegetative cover pilot test at the $1^{\text {st }}$ and $3^{\text {rd }}$ years after installation. 
microbes [32]. The most observable functions of soil organic matter include positive changes of soil physical properties such as bulk density, aggregate stability, porosity and water holding capacity when applied for long periods [33-34]. Generally, increased organic matter content of soils results in an increase in stability, irrespective of the origin of the stress [35].

Plant growth was more significantly improved in the composite ET cover of soil and bottom ash compared to that in the single soil ET cover (Figure 3). The beneficial effect of the composite ET cover on improving plant biomass growth increased over the study years. Several studies have been conducted on use and disposal of coal by-products as soil amendments [29]. Bottom ash is a relatively coarse, gritty material in contrast to fly ash, which consists of very fine particles. As shown in Table 2, most components of soil fertility were significantly more favorable to plant growth in the composite ET cover soil than the single soil ET cover. As a result, the improvement of soil fertility might have become more effective in enhancing plant biomass growth in the composite ET cover.

There was a slight increase in the amounts of $0.1 \mathrm{M}$ $\mathrm{HCl}$-extractable heavy metals such as $\mathrm{Cu}, \mathrm{Pb}$ and $\mathrm{Zn}$, following the additions of bottom ash (Table 2). However, these values for heavy metals that were detected in this pilot experiment were lower than the criteria for soil pollution as regulated by the Korean government at 200 $\mathrm{mg} \cdot \mathrm{kg}^{-1}, 400 \mathrm{mg} \cdot \mathrm{kg}^{-1}$ and $800 \mathrm{mg} \cdot \mathrm{kg}^{-1}$ of $\mathrm{Cu}, \mathrm{Pb}$ and $\mathrm{Zn}$, respectively. Williams et al. [36] tested the land application of bark broiler bottom ash on moderately well drained Atlantic Coastal Plain soils and their findings revealed that the bottom ash application did not show any adverse effect of heavy metal pollution such as As, $\mathrm{Cd}, \mathrm{Cu}, \mathrm{Cr}, \mathrm{Ni}$ on soil or ground water quality at the maximum application rates $\left(44 \mathrm{Mg} \cdot \mathrm{ha}^{-1}\right)$. As a result, our pilot system study indicates that bottom ash as mixing material in the ET cover system has potential as a good soil additive that will not be detrimental to soil, plants, or the environment.

To conclude, manure compost was very effective to enhance the growth of three selected plants (Cosmos bipinnatus, Lespedeza cuneata, Lespedeza cyrtobotrya) in the composite ET cover system made of soil and bottom ash, and ca. $40 \mathrm{Mg} \cdot \mathrm{ha}^{-1}$ of compost could be a reasonable application level in a sterile ET cover soil. Manure compost application significantly increased total plant biomass productivity, and might have stabilized the early vegetation development in the ET cover system. The effect of compost application on vegetative stabilization was more significantly improved in the composite ET cover of soil and bottom ash than that in the single soil ET cover, mainly due to a more favorable soil fertility conditions such as high content of organic matter,

Table 2. Chemical properties of ET vegetation media made of the composite of soil (65\%) and coal bottom ash (35\%), and the single soil collected in the vegetative cover pilot test at plant harvesting stage in the $3^{\text {rd }}$ year after installation.

\begin{tabular}{|c|c|c|c|c|c|}
\hline \multirow{2}{*}{$\begin{array}{l}\text { ET cover material } \\
\text { Compost application }\left(\mathrm{Mg} \cdot \mathrm{ha}^{-1}\right)\end{array}$} & \multicolumn{2}{|c|}{ Single soil } & \multicolumn{2}{|c|}{ Composite of BA and soil } & \multirow{2}{*}{$\mathrm{LSD}_{0.05}$} \\
\hline & 0 & 40 & 0 & 40 & \\
\hline $\mathrm{pH}\left(\mathrm{H}_{2} \mathrm{O}, 1: 5\right)$ & 5.57 & 5.53 & 7.79 & 7.56 & 0.33 \\
\hline Electrical conductivity $\left(\mathrm{dS} \cdot \mathrm{m}^{-1}\right)$ & 0.14 & 0.23 & 0.37 & 0.36 & 0.09 \\
\hline Organic matter $\left(\mathrm{g} \cdot \mathrm{kg}^{-1}\right)$ & 1.6 & 2.1 & 32.3 & 36.4 & 6.44 \\
\hline Available $\mathrm{P}\left(\mathrm{mg} \cdot \mathrm{kg}^{-1}\right)$ & 3.7 & 5.7 & 116.9 & 141.9 & 3.83 \\
\hline \multicolumn{6}{|l|}{ Exchangeable cation $\left(\mathrm{cmol}^{+} \cdot \mathrm{kg}^{-1}\right)$} \\
\hline $\mathrm{K}$ & 0.28 & 0.41 & 0.28 & 0.37 & 0.01 \\
\hline $\mathrm{Ca}$ & 3.16 & 3.93 & 3.49 & 6.89 & 0.30 \\
\hline $\mathrm{Mg}$ & 1.02 & 1.10 & 3.01 & 2.60 & 0.05 \\
\hline $\mathrm{Na}$ & 0.11 & 0.11 & 0.46 & 0.21 & 0.01 \\
\hline \multicolumn{6}{|l|}{$0.1 \mathrm{~N} \mathrm{HCl}$ extractable $\left(\mathrm{mg} \cdot \mathrm{kg}^{-1}\right)$} \\
\hline As & nd & nd & nd & nd & - \\
\hline $\mathrm{Cd}$ & nd & nd & nd & nd & - \\
\hline $\mathrm{Cu}$ & nd & 1.06 & 4.39 & 4.16 & 0.19 \\
\hline $\mathrm{Cr}$ & nd & nd & nd & nd & - \\
\hline $\mathrm{Ni}$ & nd & nd & nd & nd & - \\
\hline $\mathrm{Pb}$ & nd & nd & nd & 1.71 & 0.46 \\
\hline $\mathrm{Zn}$ & 0.57 & 1.72 & 3.13 & 8.47 & 0.38 \\
\hline
\end{tabular}

Note: BA and nd mean bottom ash and not detected, respectively. 
available inorganic elements, and neutral $\mathrm{pH}$ promoting plant growth. The bottom ash as a mixing material of soil in the ET cover system has a strong potential as an alternative to fine soil, and manure compost addition can effectively stimulate vegetative stabilization in the ET cover system.

\section{REFERENCES}

[1] US Environmental Protection Agency (1989) Final covers on hazardous waste landfill and surface impoundments.

[2] Jesionek, K.S., Dunn, R.J. and Daniel, D.E. (1995) Evaluation of landfill final covers. Proceedings of the 5th International Landfill Symposium, Sardinia, 2-6 October 1995, pp. 509-532.

[3] Lundgren, T (1995) Sluttäckning av avfallsupplag-krav, material, utförande, kontroll. Swedish Environmental Protection Agency, Sweden.

[4] Othman, M.A., Bonaparte, R., Gross, B.A. and Schmertmann, G.R. (1995) Design of MSW landfill cover systems. Geotechnical Special Publications, 53, 218-257.

[5] Elshorbagy, W.A. and Mohamed, A.M.O. (2000) Evaluation of using municipal solid waste compost in landfill closure caps in arid areas. Waste Management, 20, 499507. doi:10.1016/S0956-053X(00)00025-8

[6] Mollamahmutoglu, M. and Yilmaz, Y. (2001) Potential use of fly ash and bentonite mixture as liner or cover at waste disposal areas. Environmental Geology, 40, 13161324. doi: $10.1007 / \mathrm{s} 002540100355$

[7] Kim, S.O., Kim, P.J. and Yu, C. (2008) Evaluation on feasibility of industrial by-products for development of mono-layer landfill cover system. Journal of Korean Society of Environmental Engineers, 30, 1075-1086.

[8] Yun, S.W., Kang, S.I., Jin, H.G., Kim, P.J., Kim, S.O. and Yu. C. (2010) Evaluation on the effect of coal-ash as landfill cover material of mono-layer cover system through the field scale test. Geotechnical Engineering, 26, 81-91.

[9] Korcak, R.F. (1995) Utilization of coal combustion by-products in agriculture and horticulture. In: Karlen, D.L., Wright, R.J. and Kemper W.O., Eds., Agriculture Utilization of Urban and Industrial By-Products, ASACSSA-SSSA, Madison, 107-130.

[10] Dobson, M.C. and Moffat, A.J. (1995) A re-evaluation of objections to tree planting on containment landfills. Waste Management and Research, 13, 579-600.

[11] National Institute of Agricultural Sciences and Technology (2007) Water management in upper soil. National Institute of Agricultural Science and Technology, Korea Rural Development Administration, Suwon.

[12] Korea Meterological Administration (2012) Monthly report of automatic weather system data from January to December. Korea Meteorological Administration, Seoul.

[13] Allison, L.E. (1965) Organic carbon. In: Black C.A., Ed., Methods of Soil Analysis, ASA-CSSA-SSSA, Madison, 1367-1389.

[14] Rural Development Administration (1988) Method of soil chemical analysis. National Institute of Agricultural Science and Technology, Suwon.

[15] Rural Development Administration (1999) Fertilization standard of crop. National Institute of Agricultural Science and Technology, Suwon.

[16] Ozores-Hampton, M. and Obreza, T.A. (1999) Composted waste use on Florida vegetable crops: A review. In: Warman, P.R. and Taylor, B.R., Eds., Proceedings of the International Composting Symposium, CBA Press, Truro, Halifax, 827-842.

[17] Evanylo, G.K. and Daniels, W.L. (1999) Paper mill sludge composting and compost utilization. Compost Science and Utilization, 7, 30-39.

[18] Arrouge, T., Moresoli, G. and Soucy, G. (1999) Primary and secondary sludge composting: A feasibility study. Pulp and Paper Canada, 100, 33-36.

[19] Edwards, L., Burney, J.R., Richter, G. and MacRae, A.H. (2000) Evaluation of compost and straw mulching on soil-loss characteristics in erosion plots of potatoes in Prince Edwards Island, Canada. Agriculture, Ecosystems and Environment, 81, 217-222. doi:10.1016/S0167-8809(00)00162-6

[20] Cha, D.W., Lee, H.S. and Jung, J.H. (1999) Production and composition of the power plant coal ash in Korea. Proceedings of Agricultural Utilization of Fly Ash Symposium. Gyeongsang National University, Chinju, 1-23.

[21] Moliner, A.M. and Street, J.J. (1982) Effect of fly ash and lime on growth and composition of corn (Zea mays L.) on acid sandy soils. Soil and Crop Science Society of Florida Proceedings, 41, 217-220.

[22] Elseewi, A.A., Grimm, S.R., Page, A.L. and Straughan, I.R. (1981) Boron enrichment of plants and soils treated with coal ash. Journal of Plant Nutrition, 3, 409-427. doi:10.1080/01904168109362848

[23] Druzina, V.D., Miroshrachenko, E.D. and Chertov, O.D. (1983) Effect of industrial pollution on nitrogen and ash content in meadow phytocoenotic plants. Botanicheskii Zhurnal, 68, 1583-1591.

[24] Wong, M.H. and Wong, J.W.C. (1989) Germination and seedling growth of vegetable crops in fly ash amended soils. Agriculture, Ecosystems and Environment, 26, 23 35. doi:10.1016/0167-8809(89)90035-2

[25] Ko, B.G. (2000) Effects of fly ash and gypsum application on soil improvement and rice cultivation. Ph.D. Dissertation, Gyeongsang National University, Chinju.

[26] Lee, H., Ha, H.S., Lee, C.H., Lee, Y.B. and Kim, P.J. (2006) Fly ash effect on improving soil properties and rice productivity in Korean paddy soils. Bioresource Technology, 97, 1490-1497. doi:10.1016/j.biortech.2005.06.020

[27] Lee, C.H., Lee, H., Lee, Y.B., Chang, H.H., Ali, M.A., Min, W., Kim, S. and Kim. P.J. (2007) Increase of available phosphorus by fly-ash application in paddy soils. Communications in Soil Science and Plant Analysis, 38, 1551-1562. doi:10.1080/00103620701378482

[28] Adriano, D.C., Woodford, T.A. and Ciravolo, T.G. (1978) Growth and elemental composition of corn and bean seedlings as influenced by soil application of coal ash. 
Journal of Environmental Quality, 7, 416-421. doi:10.2134/jeq1978.00472425000700030025x

[29] Adriano, D.C., Page, A.L., Elseewi, A.L., Chang, A.C. and Straughan, I. (1980) Utilization and disposal of fly ash and other coal residues in terrestrial ecosystems: A review. Journal of Environment Quality, 9, 333-344. doi:10.2134/jeq1980.00472425000900030001x

[30] Page, A. L., Elseewi, A.A. and Straughan, I.R. (1979) Physical and chemical properties of fly ash from coalfired power plants with reference to environmental impacts. Residue Reviews, 71, 83-20. doi:10.1007/978-1-4612-6185-8_2

[31] Bongiovanni, M.D. and Lobartini, J.C. (2006) Particulate organic matter, carbohydrate, humic acid contents in soil macro- and microaggregates as affected by cultivation. Geoderma, 136, 660-665. doi:10.1016/j.geoderma.2006.05.002

[32] Senesi, N. and Loffredo, E. (1999) The chemistry of soil organic matter. In: Spark, D.L., Ed., Soil Physical Chem- istry, CRC Press, Boca Raton, 239-370.

[33] Edwards, C.A. and Lofty, J.R. (1982) Nitrogenous fertilizers and earthworms populations in agricultural soils. Soil Biology and Biochemistry, 147, 515-521. doi:10.1016/0038-0717(82)90112-2

[34] Schjonning, P. and Christensen, B.T. (1994) Physical and chemical properties of a sandy loam receiving animal manure, mineral fertilizer or no fertilizer for 90 years. European Journal of Soil Science, 45, 257-268. doi:10.1111/j.1365-2389.1994.tb00508.x

[35] Kay, B.D. (1998) Soil structure and organic carbon: A review. In: Lal, R., et al., Ed., Soil Processes and the Carbon Cycle, CRC Press, Boca Raton, 169-197.

[36] Williams, T.M., Charles, A.H. and Smith, B.H. (1996) Forest soil and water chemistry following bark broiler bottom ash application. Journal of Environment Quality, 25, 955-961. doi:10.2134/jeq1996.00472425002500050005x 